\title{
PENERAPAN UNDANG-UNDANG TINDAK PIDANA KORUPSI DALAM MENANGANI KEJAHATAN PERBANKAN
}

\author{
Linda Hindriana, Neni Sri Imaniyati \\ Alumni Magister Program Studi Kenotariatan \\ Pascasarjana Universitas Islam Bandung. \\ Email : lindahindriana@yahoo.co.id
}

\begin{abstract}
Abstrak : Perkembangan zaman, perkembangan ilmu pengetahuan, perkembangan ekonomi dan perdagangan memacu perkembangan tindak pidana korupsi. Korupsi merupakan suatu kejahatan yang sangat kompleks. Korupsi tidak saja terjadi pada sektor publik tapi merambah pada sektor swasta manakala aktifitas bisnisnya berhubungan atau terkait dengan sektor publik seperti sektor perbankan dan pelayanan publik. Perkembangan tindak pidana korupsi di bidang perbankan berkembang seiring meningkatnya industri perbankan sebagai lokomotif pembangunan nasional. Tujuan penelitian ini adalah untuk menganalisis faktor-faktor yang terjadi tindak pidana korupsi di bidang perbankan dan untuk menganalisis peran Bank Indonesia dalam upaya penanggulangan tindak pidana. Metode penelitian ini menggunakan metode yuridis normatif. Data yang digunakan data sekunder. Teknik Pengambilan data melalui studi kepustakaan. Hasil penelitian diperoleh bahwa terjadinya tindak pidana korupsi dibidang perbankan disebabkan beberapa aspek yaitu aspek individu pelaku yang berasal dari diri pelaku itu sendiri, aspek organisasi, aspek masyarakat dan aspek peraturan perundang-undangan, serta penegakan hukum dalam pencegahan dan pemberantasan korupsi di perbankan dapat dilakukan melalui sarana penal (penggunaan hukum pidana dan hukum administrasi pidana) dan non penal (peningkatan sistem pengawasan, penerapan prinsip kehati-hatian, financial safety net, dan penetapan sistem perbankan yang mengarah kepada praktik good corporate goverance.
\end{abstract}

\section{Kata Kunci: Kejahatan, Perbankan, Tindak Pidana, Korupsi}

Abstract : The development of the times, science, economy, and trade have triggered the development of corruption and anti-corruption. Corruption is a very complex crime. It does not only occur in the public sector, but also in the private sector when its business activities are related to the public sector, such as the banking and public service sectors. The development of corruption and anticorruption in the banking sector is growing with the increase in the banking industry as a national development locomotive. The purpose of this study is to analyze the factors that have occurred in the banking sector and determine the role of Bank Indonesia in the efforts to overcome criminal acts. This study used a normative juridical method by using secondary data through library study as its data collection method. The result showed that the occurrence of criminal acts of corruption in the banking sector is caused by several aspects, namely the aspects of individual originating from the perpetrators themselves, organizational, society, laws and regulations. Additionally, law enforcement in the prevention and eradication of corruption in banking can be conducted through a means of penal (the use of criminal law and criminal administrative law) and non-penal (improved supervision systems, application of prudential principles, financial safety net, and determination of banking that lead to good corporate governance practices.

Keywords : Crime, Banking, Criminal Act, Corruption 


\section{A. PENDAHULUAN}

Lembaga perbankan bekerja berdasarkan kepercayaan masyarakat yang memegang peranan penting dalam sistem perekonomian, sehingga sering dikatakan bank sebagai jantung perekonomian yang memfasilitasi keperluan berbagai pihak, pemerintah swasta, rumah tangga, perorangan dan lain-lain. Mengingat pentingnya peranan perbankan dan besarnya dana yang dikelola oleh perbankan, maka berbagai pihak bank intern perbankan (pemilik, pengurus, dan pegawai bank) maupun ekstern nasabah bank dan pihak luar lainnya) memanfaatkan bank untuk kepentingan pribadi dengan melanggar ketentuan Pidana baik yang diatur dalam UndangUndang Perbankan maupun peraturan perundang-undangan. Dalam UndangUndang Nomor 7 Tahun 1992 tentang Perbankan sebagaimana telah diubah dengan Undang- Undang Nomor 10 Tahun 1998, telah ditetapkan beberapa ketentuan yang dimaksudkan untuk mencegah dilakukannya tindak pidana di bidang perbankan.

Sebagai lembaga penghimpun dan penyalur dana masyarakat dalam menjalankan usahanya, dimana dana yang dikumpulkan bank bukanlah jumlah yang sedikit, bank harus berlandaskan dengan prinsip kehati-hatian. Sedikit saja kesalahan yang dilakukan oleh bank dalam mengelola dana dari masyarakat, maka akibatnya bisa fatal. Hubungan yang terjalin antara bank dengan nasabah tersebut haruslah disertai dengan hak dan kewajiban yang harus dipatuhi kedua belah pihak. Jika salah satu pihak melakukan perbuatan yang dapat merugikan pihak lainnya dengan cara-cara yang melawan ketentuan hukum di bidang perbankan yang berlaku, maka perbuatan salah satu pihak tersebut dikategorikan sebagai tindak pidana perbankan atau tindak pidana di bidang perbankan. (Moch. Anwar. 1986).

Suatu perbuatan dikatakan merupakan tindak pidana atau perilaku melanggar hukum pidana hanyalah apabila suatu ketentuan pidana yang telah ada menentukan bahwa perbuatan itu merupakan tindak pidana. Terkait dengan masalah tindak pidana perbankan, Sutan Remy Sjadeini, mengemukakan yang dimaksud dengan tindak pidana adalah perilaku yang melanggar ketentuan pidana yang berlaku ketika pelaku itu melakukan, baik perilaku tersebut berupa melakukan perbuatan tertentu yang dilarang oleh ketentuan pidana maupun tidak melakukan perbuatan tertentu yang diwajibkan oleh ketentuan pidana. (Sutan Remy Sjahdeini, $2006: 26-17$ ). 
Munir Fuady, berpendapat bahwa kejahatan bank makin meningkat dewasa ini, modus operandinya pun makin canggih. Bahkan, dalam beberapa kasus, terlibat sindikat mafia, baik dari dalam maupun dari luar negeri. Di samping itu, lebih dari $90 \%$ kejahatan bank dilakukan melalui kerja sama orang luar dan orang dalam bank. Uniknya, orang dalam tersebut terdiri dari para young urban profesional (Yuppies) Indonesia, dengan ciri-ciri yang sama, yaitu muda, pintar, gesit, workaholic, ambisius, punya posisi baik, punya penghasilan, dan memiliki angan-angan tinggi. Bahkan mereka menggunakan komputer sebagai sarana kejahatannya. Lalu populerlah apa yang sering disebut sebagai kejahatan komputer yang merupakan salah satu kristal dari kejahatan kerah putih (white collar crime). (Munir Fuady, 1996 : 144).

Istilah ini pertama kali digunakan oleh Edwin Sutherland pada tahun 1939. White collar crime adalah kejahatan yang dilakukan orang-orang yang mempunyai kedudukan sosial yang tinggi dan terhormat dalam melakukan pekerjaannya. Menurut kepolisian RI White collar crime adalah kejahatan yang dilakukan oleh orang-orang dari kalangan sosial ekonomi tingkat atas dalam hubungannya dengan kegiatan pekerjaan atau jabatannya.
Kejahatan perbankan tidak hanya dijerat dengan Undang-undang perbankan, namun sektor perbankan merupakan sektor/bidang yang rawan tindak pidana korupsi. Karena perbankan merupakan lembaga keuangan yang fungsi utamanya sebagai penghimpun dan penyalur dana masyarakat. Perkembangan tindak pidana korupsi di bidang perbankan berkembang seiring meningkatnya industri perbankan sebagai lokomotif pembangunan nasional. Dampak terjadinya tindak pidana korupsi di bidang perbankan bukan saja bagi pihak yang menjadi korban, namun akan menimbulkan kesan negatif bagi lembaga keuangan/perbankan itu sendiri. Hal ini disebabkan karena bank adalah lembaga yang mekanisme operasionalnya berasaskan pada hubungan kepercayaan (fiduary relation), hubungan kerahasian (confidental relation) dan hubungan kehati-hatian (prudential relation). (M. Sholehuddin, 1997 : 3).

Perkembangan tindak pidana korupsi pertama kali dilansir oleh Kongres Perserikatan bangsa-Bangsa (PBB) mengenai The Prevention of Crime and the Treatment of Offender. Para anggota PBB menyadari bahwa kejahatan korupsi telah melampaui batas-batas teritorial masing-masing negara. Tetapi laju perkembangan ekonomi dan 
perdagangan sebenarnya turut memacu perkembangan tindak pidana korupsi. Korupsi merupakan suatu kejahatan yang sangat kompleks. Dari sudut politik, korupsi merupakan faktor yang mengganggu dan mengurangi kredibilitas pemerintah. Dari sudut ekonomi, korupsi merupakan salah satu faktor yang menimbulkan kerugian keuangan negara dalam jumlah besar. Dari sudut budaya, korupsi merusak moral dan karakter bangsa Indonesia yang menjunjung tinggi nilai-nilai luhur. (Edi Setiadi dan Rena Yulia, $2010: 68)$.

Korupsi tidak saja terjadi pada sektor publik, namun bisa juga merambah pada sektor swasta Ketika aktifitas bisnisnya berhubungan atau terkait dengan sektor publik seperti sektor perpajakan, perbankan dan pelayanan publik. Salah satu Kejahatan perbankan yaitu penyalahgunaan dana BLBI mengarah tindak pidana Korupsimemperkaya diri sendiri/kelompoknya dengan merugikan keuangan negara dan hak-hak sosial masyarakat (Pasal 1,2,3 dan 4 UU No. 31 tahun 1999 tentang Tindak Pidana Korupsi jo perubahannya UU No. 20 Tahun 2001) atau setidaktidaknya penggelapan. (Pasal 327 KUHPidana) dan Perbuatan melanggar hukum (Pasal 1365 KUHPerdata).
Kejahatan Perbankan pemberian kredit dengan memakai dana APBD, apabila terjadi kemacetan akan dijerat Undang-Undang Tindak Pidana Korupsi, seperti contoh dalam kasus pemberian kredit atas proyek pembangunan PLTU 2x7 Mega Watt (MW) Sampit, Kalimantan Tengah, berdasarkan dakwaan Berdasarkan uraian tersebut, ada dua permasalahan yang Pertama, apa faktor terjadinya tindak pidana korupsi di bidang perbankan. Kedua, bagaimanakah peran Bank Indonesia dalam upaya penanggulangan tindak pidana Perbankan. Dari kedua permasalahan itu, Tujuan permasalahan untuk mengetahui dan menganalisis faktor-faktor terjadinya tindak pidana korupsi di bidang perbankan. kedua, untuk mengetahui dan menganalisis peran Bank Indonesia dalam upaya penanggulangan tindak pidana Perbankan.

Para Terdakwa bersama-sama melakukan penyalahgunaan fasilitas kredit yang diberikan PT Bank Mandiri Tbk (Mandiri). Dimana seharusnya digunakan untuk pembiayaan pembangunan PLTU 2x7 MW (mega watt) di Sampit, Kalteng, sebagai realisasi perjanjian PT Karya Putra Powerin (KPP) dengan PT PLN wilayah Kalimantan Selatan dan Tengah (Kaselteng). Namun, alih-alih membiayai 
pembangunan PLTU 2x7 MW, kedua terdakwa malah menggunakan kucuran kredit tersebut untuk membiayai keperluan pribadi, serta perusahaan (MI) dan anak-anak perusahaan mereka.

\section{B. PEMBAHASAN}

1. Bentuk-bentuk Tindak Pidana Korupsi

Tindak Pidana Korupsi adalah suatu tindak pidana yang dengan penyuapan manipulasi dan perbuatanperbuatan melawan hukum yang merugikan atau dapat merugikan keuangan negara atau perekonomian negara, merugikan kesejahteraan atau kepentingan rakyat/umum.

Adapun definisi yang sering dikutip adalah; Tingkah laku yang menyimpangdari tugas-tugas resmi sebuah jabatan Negara karena keuntungan status atau uang yang menyangkut pribadi (perorangan, keluarga dekat, kelompok sendiri); atau melanggar aturan-aturan pelaksanaan beberapa tingkah laku pribadi. (Robert Klitgaard, $2001: 31$ ).

Tindak Pidana Korupsi pada umumnya memuat efektivitas yang merupakan manifestasi dari perbuatan korupsi dalam arti luas mempergunakan kekuasaan atau pengaruh yang melekat pada seseorang pegawai negeri atau istimewa yang dipunyai seseorang didalam jabatan umum yang patut atau menguntungkan diri sendiri maupun orang yang menyuap sehingga dikualifikasikan sebagai tindak pidana korupsi dengan segala akibat hukumnya yang berhubungan dengan hukum pidana.

Rumusan yuridis formal istilah korupsi di Indonesia ditetapkan dalam bab II pada Pasal 2-16 Undang-undang Nomor 31 Tahun 1999 Tentang Pemberantasan Tindak Pidana Korupsi: (7Undang-undang RI Nomor 31 Tahun 1999, $2003: 80-84)$.

a. (1) Setiap orang yang secara melawan hukum melakukan perbuatan memperkaya diri sendiri atau orang lain atau suatu korporasi yang dapat merugikan keuangan Negara atau perekonomian Negara.

(2) Dalam hal tindak korupsi sebagai mana dimaksud dalam ayat (1) dilakukan dalam keadaan tertentu, pidana mati dapat dijatuhkan.

b. Setiap orang yang dengan tujuan menguntungkan diri sendiri atau orang lain atau suatu korporasi, menyalahgunakankewenangan, kesempatan atau sarana yang ada padanya karena jabatan atau kedudukan yang dapat merugikan 
keuntungan Negara atau perekonomian Negara.

c. Setiap orang yang melakukan tindak pidana sebagaimana dimaksud dalam Pasal 209, 210, $387,415,416,417,418,419,420$, 423, 425, dan 435 KUHP.

d. Setiap orang yang melanggar undang-undang yang secara tegas menyatakan bahwa pelanggaran terhadap ketentuan undangundang tersebut sebagai tindak pidana korupsi berlaku ketentuan yang diatur dalam undang-undang ini.

e. Setiap orang yang melakukan percobaan, pembantuan, atau permufakatan jahat untuk melakukan tindak pidana korupsi, dipidana dengan pidana yang sama sebagaimana dimaksud dalam Pasal 2, Pasal 3, Pasal 5 sampai dengan Pasal 14.

f. Setiap orang di luar wilayah Negara Republik Indonesia yang memberikan bantuan, kesempatan, sarana atau keterangan untuk terjadinya tindak pidana korupsi dipidana dengan pidana yang sama sebagaimana pelaku tindak pidana korupsi sebagaimana dimaksud dalam Pasal 2, Pasal 3, Pasal 5 sampai dengan Pasal 14.
Kemudian dalam Undang-undang Nomor 20 Tahun 2002 Tentang Perubahan Atas Undang-undang RI Nomor 31 Tahun 1999 Tentang Pemberantasan Tindak Pidana Korupsi ada pemberantasan beberapa item yang digolongkan tindak pidana korupsi, yaitu mulai Pasal 5 sampai dengan Pasal 12. Pada Pasal 5 misalnya memuat ketentuan tentang penyuapan terhadap pegawai negeri atau penyelenggaraan Negara, Pasal 6 tentang penyuapan terhadap hakim dan advokat. Pasal 7 memuat tentang kecurangan dalam pengadaan barang atau pembangunan, dan seterusnya.

Berdasarkan ketentuan di atas, dapat disimpulkan bahwa unsur-unsur tindak pidana korupsi meliputi ; melawan hukum, memperkaya diri sendiri atau orang lain atau korporasi, dan merugikan keuangan negara atau perekonomian negara. Apabila dikaji karakteristiknya, kejahatan korupsi mempunyai ciri-ciri sebagai berikut: (Edi Setiadi, 2004 : 43).

1) Kejahatan tersebut sulit dilihat, karena biasanya tertutup oleh kegiatan pekerjaan yang normal dan rutin;

2) Kejahatan tersebut sangat kompleks karena selalu berkaitan dengan kebohongan, penipuan dan pencurian;

3) Terjadi penyebaran tanggung jawab yang semakin meluas akibat kompleksitas organisasi; 
4) Penyebaran korban yang luas hambatan dalam pendeteksian dan penuntutan akibat kurang profesionalnya aparat;

5) Peraturan yang tidak jelas sehingga merugikan dalam penegakan hukum;

6) pandangan yang mendua terhadap pelaku.

Menurut J. Soewartojo, ada beberapa bentuk tindak pidana korupsi, yaitu: (Evi Hartanti, $2005: 20$ ).

1) Pungutan liar jenis tindak pidana, yaitu korupsi uang negara, menghindari pajak dan bea cukai, pemerasan dan penyuapan.

2) Pungutan liar jenis pidana yang sulit dibuktikan, yaitu komisi dalam kredit bank, komisi dalam tender proyek, imbalan jasa dalam pemberian izin, kenaikan pangkat, pungutan terhadap uang perjalanan, pungli pada pos-pos pencegatan di jalan, pelabuhan, dan sebagainya.

3) Pungutan liar jenis pungutan tidak sah yang dilakukan oleh Pemda, yaitu pungutan yang dilakukan tanpa ketetapan berdasarkan peraturan daerah, tetapi hanya dengan surat-surat keputusan saja.

4) Penyuapan, yaitu seorang penguasa menawarkan uang atau jasa lain kepada seseorang atau keluarganya untuk suatu jasa bagi pemberi uang.

5) Pemerasan, yaitu orang yang memegang kekuasaan menuntut pembayaran uang atau jasa lain sebagai ganti atau timbal balik fasilitas yang diberikan.

6) Pencurian, yaitu orang yang berkuasa menyalagunakan kekuasaannya dan mencuri harta rakyat langsung atau tidak langsung.

7) Nepotisme, yaitu orang yang berkuasa memberikan kekuasaan dan fasilitas pada keluarga dan kerabatnya, yang seharusnya orang lain juga dapat atau berhak bila dilakukan secara adil.

Kemudian menurut Konvensi PBB Anti Korupsi tahun 2003, ada 4 (empat) tipe tindak pidana korupsi, sebagai berikut: (Lilik Mulyadi, 2007 : 41).

1) Tindak pidana korupsi penyuapan pejabat publik nasional

2) Tindak pidana korupsi penyuapan di sektor swasta

3) Tindak pidana korupsi terhadap perbuatan memperkaya secara tidak sah 4) Tindak pidana korupsi terhadap memperdagangkan pengaruh

Sedangkan menurut S. H. Alatas korupsi terjadi disebabkan oleh faktor faktor berikut: (S. H. Alatas, 1986 : 6-47). 
a. Ketiadaan atau kelemahan kepemimpinan dalam posisi-posisi kunci yang mampu memberikan ilham dan mempengaruhi tingkah laku yang menjinakkan korupsi,

b. Kelemahan pengajaran-pengajaran agama dan etika,

c. Kolonialisme,

d. Kurangnya pendidikan,

e. Kemiskinan,

f. Tiadanya hukuman yang keras,

g. Kelangkaan lingkungan yang subur untuk perilaku anti korupsi,

h. Struktur pemerintahan,

i. Perubahan radikal, dan

j. Keadaan masyarakat.

\section{Bentuk-bentuk Tindak Pidana} Perbankan

Istilah "tindak pidana perbankan" harus dibedakan dengan istiah "tindak pana dibiang perbankan" dalam tulisannya yang berjudul Penegakan Hukum dan Upaya Pencegahan terhadap Kejahatan Perbankan menyatakan bahwa tindak piana perbankan adalah tindak pisana yang semata-mata dilakukan oleh bank atau orang termasuk didalamnya pemegang saham bank, yang pengaturannya tercantum dalam Undang-Undang Perbankan. (Ahmad Fuad, Penegakan Hukum dan Upaya Pencegahan Terhadap Kejahatan Perbankan, Makalah disampaikan pada Seminar Nasional
Penegakan Hukum dan Upaya Pencegahan Terhadap Kejahatan Perbankan, Sekolah Tinggi Hukum Bandung (STHB), 16 Juni 2011).

Kejahatan perbankan dapat diartikan sebagai "tindak pidana di bidang perbankan" yang dalam pengertian ini mencakup segala perbuatan yang melanggar hukum yang ada kaitannya dengan bisnis perbankan.

Tindak pidana perbankan adalah tindak pidana yang menjadikan bank sebagai sarana (crimes through the bank) dan sasaran tindak pidana itu (crimes against the bank).

Para ahli yang menggunakan istilah "kejahatan perbankan" argumentasi yang dikemukakan cenderung bermuara para kejahatan kerah putih yang dipopulerkan oleh E. H. Suterland. Secara konseptual kejahatan kerah putih ini digunakan untuk mengindentifikasikan kejahatan yang dilakukan oleh kalangan pengusaha/eksekutif dan pejabat yang akibatnya merugikan kepentingan umum. Oleh karena pelaku perbuatan melanggar hukum di bidang perbankan dapat dikatakan hampir semuanya berasal dari kalangan pengusaha/eksekutif dan pejabat, maka istilah yang dipakai adalah kejahatan perbankan. (M. Sholehuddin, 1997 : 9).

Lebih spesifik, tindak piana atau kejahatan perbankan dpat dikatakan 
sebagai kejahatan kerah putih (white collar crime) karena beberapa hal berikut ini: (Kristian dan Yopi Gunawan, 2013 : 18).

a. Tindak pidana ini dilakukan dengan suatu proses, prosedur dan cara yang sangat murni;

b. Dilakukan dengan menggunakan sarana0sarana tertentu (teknologiteknologi tertentu);

c. Dilkakukan oleh kalangan profesi tertentu yang ahli dibidangnya atau dalam melakukan pekerjaannya;

d. Dilakukan tidak oleh satu orang melainkan beberapa orang yang terstruktur dan tersistematisasi;

e. Dilakukan dengan penyalahgunaan kekuasaan dan jabatan dimana hal tersebut merupakan pelanggaran terhadap warga negara;

f. Merupakan atau dapat dikategorikan sebagai tindak piana korporasi

Dalam Undang-Undang No. 10 tahun 1998 tentang Perbankan tidak merumuskan tentang pengertian tindak pidana perbankan. Undang-undang ini hanya mengkategorikan beberapa perbuatan yang termasuk dalam kejahatan, dan beberapa perbuatan yang termasu pelanggaran. Jadi undang- undang perbankan hanya mengklasifikasikan suatu perbuatan bukan merumuskan pengertian kejahatan perbankan/tindak pidana perbankan.
Beberapa perbuatan yang dapat dikategorikan sebagai kejahatan perbankan dan telah diatur dalam perundangundangan lain adalah :

1) Dalam KUHP, Buku II Bab $X$ tentang Pemalsuan Mata Uang dan Uang Kertas, yaitu Pasal 244, 245, 246, 249 dan 250.

2) Dalam Undang-Undang Nomor 10 Tahun 1998 ;

a. Pasal 46 : menjalankan usaha bank tanpa ijin Menteri Keuangan

b. Pasal 47: larangan bagi bank untuk memberikan keterangan tentang keadaan keuangan nasabahnya yang tercatat padanya dan hal-hal lain yang harus dirahasiakan oleh Bank menurut kelajiman dalam dunia perbankan

c. Pasal 47 a: memberi keterangan tentang hal-hal yang harus dirahasiakan oleh anggota direksi atau pegawai bank Pasal 48 : dengan sengaja tidak memberikan keterangan yang wajib diberikan oleh anggota direksi atau pegawai bank

3) Dalam Undang-Undang No. 13. Tahun 1968 tentang Bank Sentral. 
Pasal 59 ayat (2) menentukan bahwa tindak pidana berupa kejahatan apabila Gubernur, Direktur dan pegawai bank, komisaris pemerintah serta sekretariat dewan moneter dan pegawai sekretariat dewan komisaris pemerintah memberikan keterangan yang diperoleh karena jabatannya kecuali apabila diperlukan untuk pelaksanaan tugasnya atau untuk memenuhi kewajiban-kewajiban menurut undang-undang ini.

3. Faktor-faktor

Yang
Terjadinya

\section{Korupsi di Bidang Perbankan}

Pada dasarnya, korupsi merupakan suatu tindakan menyimpang yang dapat terjadi kapanpun dan dimanapun, sepanjang insentif yang dihasilkan cukup besar. Penyakit korupsi ini bisa terjadi di sektor publik maupun swasta, bahkan di tingkat masyarakat.

Selain itu sulitnya memberantas kejahatan perbankan disebabkan pelaku menggunakan modus operandi yang sulit dibedakan dengan modus operandi ekonomi lainnya, kemudian tindak pidana perbankan ini memerlukan penanganan yang khusus dari aparat penegak hukum. Faktor penyebab korupsi di bidang perbankan dapat pula diamati dari berbagai aspek. Aspek pelaku, aspek lingkungan/masyarakat, aspek peraturan perundang-undangan dapat dijadikan bahan penilaian penyebab korupsi di bidang perbankan.

Seperti halnya dalam kejahatan Perbankan pemberian kredit dengan memakai dana APBD, apabila terjadi kemacetan akan dijerat Undang-Undang Tindak Pidana Korupsi, seperti contoh dalam kasus pemberian kredit atas proyek pembangunan PLTU 2x7 Mega Watt (MW) Sampit, Kalimantan Tengah, berdasarkan dakwaan Para Terdakwa bersama-sama melakukan penyalahgunaan fasilitas kredit yang diberikan PT Bank Mandiri Tbk (Mandiri). Dimana seharusnya digunakan untuk pembiayaan pembangunan PLTU 2x7 MW (mega watt) di Sampit, Kalteng, sebagai realisasi perjanjian PT Karya Putra Powerin (KPP) dengan PT PLN wilayah Kalimantan Selatan dan Tengah (Kaselteng). Namun, alih-alih membiayai pembangunan PLTU $2 \times 7$ MW, kedua terdakwa malah menggunakan kucuran kredit tersebut untuk membiayai keperluan pribadi, serta perusahaan (MI) dan anak-anak perusahaan mereka. 
Penuntut umum mengenakan

UU Korupsi, karena melihat modus operandi dan kepemilikan saham di Bank Mandiri. Selain itu, korupsi masih dianggap sebagai extra ordinary crime yang harus diprioritaskan

penanggulangan

dan

pemberantasannya. Atas dugaan penyalahgunaan fasilitas kredit Bank Mandiri ini, penuntut umum mengenakan Pasal 2 ayat (1) $18 \mathrm{UU}$ Pemberantasan Tindak Pidana Korupsi (UU Korupsi) jo Pasal 55 ayat (1) ke-1 KUHP, dan Pasal 3 jo Pasal 18 UU Korupsi jo Pasal 55 ayat (1) ke-1 KUHP kepada kedua terdakwa. Yakni, Brahmantyo Irawan Kuhandoko

(Presiden Direktur PT Mosesa International) dan Achmad Fachrie (Direktur PT Mosesa International).

Terjadinya tindak pidana korupsi dalam bidang perbankan khususnya di PT. Bank Mandiri disebabkan oleh beberapa aspek yang antara lain aspek individu pelaku yang berasal dari dalam diri pelaku itu sendiri, aspek organisasi, aspek tempat individu dan organisasi berada (aspek masyarakat) dan aspek peraturan perundang-undangan.

Untuk menanggulangi tindak pidana korupsi dalam bidang perbankan khususnya di PT. Bank Mandiri tersebut maka perlu diambil suatu langkah-langkah kebijakan berupa kebijakan non-penal dan kebijakan penal. Kebijakan nonpenal dapat dilakukan dengan menangani faktor-faktor kondusif penyebab terjadinya tindak pidana korupsi dan melalui pendekatan berdasarkan operasi perbankan yang mencakup pengelolaan dana pihak ketiga, penempatan dana bank, pemberian kredit, pengelolaan transaksi derivatif, dan kecurangan perbankan lainnya dan kebijakan penal dapat dilakukan dengan melaporkan atau menyerahkan kasus tindak pidana korupsi yang terjadi kepada pihak penegak hukum (polisi, jaksa, KPK). Untuk dapat diproses sesuai dengan ketentuan hukum yang berlaku.

Kejahatan di bidang perbankan disinyalir karena lemahnya pengawasan internal bank dari bank sentral. Hal ini bisa disebabkan oleh :

1. Ketidaktelitian melakukan pengawasan mengingat besarnya jumlah transaksi harian di bank dan kantor cabang.

2. Ketidaktahuan dalam Teknik pengawasan internal bank (lemahnya profesionalisme).

3. Adanya unsur moral hazzard, yaitu terjadinya kolusi antara pengawas bank dengan pejabat perbankan 
dari luar untuk melakukan kejahatan

Faktor penyebab korupsi di bidang perbankan dapat pula dilihat dari berbagai aspek., yaitu antara lain:

Aspek pelaku, aspek lingkungan/masyarakat, aspek peraturan perundang-undangan dapat dijadikan bahan penilaian penyebab korupsi di bidang perbankan.

a) Aspek pelaku;

Sikap serakah yang ada dalam diri pelaku bisa mendorong pelaku untukmelakukankorupsi, walaupun penghasilan yang dimilikinya sudah tinggi bahkan mungkin berlebihan. Berapa pun besarnya kekayaan yang dimiliki seseorang, apabila ada kesempatan untuk melakukan korupsi maka ia akan melakukannya juga. (Badan Pengawasan dan Pembangunan, Strategi Pemberantasan Korupsi Nasional, Edisi Maret, 1999 : 83). Moral yang tidak kuat cenderung lebih mudah tergoda untuk melakukan korupsi. Godaan ini bisa berasal dari atasan, teman setingkat, bawahan, atau pihak luar yang dilayani (nasabah) yang memberi kesempatan untuk itu. (Ibid).

Penghasilan yang kurang mencukupi kebutuhan hidup yang wajar, kebutuhan hidup yang mendesak, gaya hidup yang konsumtif, juga bisa menjadi faktor penyebab korupsi di bidang perbankan.

b) Aspek lingkungan/masyarakat; Aspek ini turut mempengaruhi perilaku seseorang untuk melakukan perbuatan korupsi. Seringkali masyarakat menghargai seseorang karena kekayaan yang dimilikinya, tanpa diimbangi dengan sikap kritis dari mana kekayaan itu berasalatau diperolehnya. Demikian juga budaya sogok menyogok jika nasabah yang ingin mendapatkan kredit dengan cepat padahal tidak memenuhi kriteria, maka dia akan menyogok pegawai bank untuk

kelancaran administrasinya. Masyarakat juga kurang berperan aktif dalam pemberantasan korupsi, karena menganggap bahwa itu adalah tugas negara, sebab keuangan negara yang dirugikan. Padahal, sebetulnya kekayaan atau keuangan negara yang dicuri tersebut akan dipergunakan dalam pembangunan demi kesejahteraan masyarakat juga.

c) Aspek peraturan perundangundangan Peraturanperundangundangan yangdikeluarkanseringkali menimbulkan banyak celah 
sehingga mudah dimanfaatkan oleh pihak-pihak yang ingin melakukan korupsi. Perumusan perundangundangan seringkali tidak disertai dengan telaah akademik, kalaupun ada itu pun hanya sekedar formalitas saja. (Badan Pengawasan dan Pembangunan, Strategi...Op.Cit, : 99-100).

Begitu pula kurang efektifnya judicial review yang dilakukan oleh Mahkamah Agung terhadap penyimpangan-penyimpangan yang terdapat dalam suatu produk hukum, faktor lain yang turut mempengaruhi adalah peraturan yang kurang disosialisasi kepada masyarakat,sehingga masyarakat awam tidak mengetahuinya.

Belum lagi penerapan sanksi yang terlalu ringan dan pandang bulu.

Menyebabkan lemahnya pemberantasan korupsi karena tidak menimbulkan efek jerah kepada pelaku. Pendayagunaan semua cara untuk memberantas kejahatan di bidang perbankan perlu dilakukan mengingat aparat penegak hukum seolaholah tidak berdaya atau tidak mempunyai kekuatan untuk melawannya, dikarenakan: (Edi Setiadi dan Rena Yulia, Op.cit : 145).

1) Kedudukan ekonomi atau politik yang kuat dari pelaku.

2) Keadaan-keadaan di sekitar perbuatan yang mereka lakukan itu sedemikian rupa sehingga menurangi kemungkinan mereka untuk dilaporkan atau dituntut.

\section{Penegakan Hukum Dalam Kejahatan}

Tindak Pidana Korupsi Dalam

Perbankan Dan Upaya

\section{Penanggulangannya.}

Penegakan hukum dalam hal pencegahan dan pemberantasan (upaya penanggulangan) korupsi di bidang perbankan dapat dilakukan melalui sarana penal (penggunaan hukum pidana dan hukum administrasi pidana) dan sarana non penal (lebih kepada peningkatan sistempengawasan, penerapan prinsip kehati-hatian, menetapkan jaring pengaman sektor keuangan (financial safety net), pemantapan sistem perbankan yang mengarahkan perbankan kepada praktik-praktik good corporate governance. serta sosialisasi terhadap masyarakat).

Dengan kata lain, corporate governance, merupakan suatu proses dan struktur yang digunakan oleh organ perusahaan (pemegang saham/pemilik modal, dewan komisaris/dewan pengawas dan direksi) untuk meningkatkan keberhasilan usaha dan akuntabilitas perusahaan guna mewujudkan atau meningkatkan nilai pemegang saham dalam jangka panjang dengan tetap 
memperhatikan kepentingan stakeholders lainnya, berlandaskan pada peraturan perundang-undangan dan nilai-nilai etika. Tentu saja GCG diberlakukan dengan tujuan untuk menciptakan nilai tambah (value added) untuk semua stakeholders. (Muh. Arief Effendi : 1).

Perolehan nilai tambah ini disebabkan GCG dapat mendorong terbentuknya pola manjemen yang bersih, transparan dan profesional. Implementasi prinsip-prinsip yang terkandung dalam GCG secara konsisten diperusahaan akan menarik minat para investor, baik domestik maupun asing. Hal ini sangat penting bagi perusahaan yang akan mengembangkan usahanya, seperti melakukan investasi baru maupun proyek ekspansi (memperluas perusahaan). (Kristian dan Yopi Gunawan, 2018 : 149).

Penegakan hukum di bidang perbankan dan kejahatan perbankan bisa dilakukan dengan berbagai cara, baik dalam bidang hukum perdata, hukum administrasi dan hukum pidana. Dalam mendukung pelaksanaan pemberantasan tindak pidana korupsi, BI telah menerapkan beberapa kebijakan strategis seperti mengeluarkan peraturan tentang prinsip Know Your Customer (KYC), Good Corparate Governance (GCG) di sektor perbankan, penerapan manajemen risiko dalam pengelolaan bank, fit \& proper test terhadap calon dan atau pemilik/pengurus/pejabat bank, serta pembentukan Surat Keputusan Bersama (SKB) antara Kejaksaan Agung RI, Kapolri dan Gubernur BI dalam rangka kerjasama penanganan tindak pidana di bidang perbankan. Disamping itu, BI telah membentuk Direktorat Investigasi dan Mediasi yang bertugas melakukan investigasi terhadap kejahatan perbankan yang membentuk Biro Informasi Kredit yang berperan meningkatkan kualitas manajemen risiko perbankan, dan governance perbankan secara keseluruhan serta pemenuhan prinsip kehati-hatian, profesionalisme aparat terus ditingkatkan sehingga mempunyai kemampuan integritas yang tinggi, mempunyai kompetensi yang cukup, serta mempunyai reputasi keuangan yang baik ataupun langkah-langkah non yuridis dalam bentuk tindakan opini masyarakat serta sosialisasi terhadap masyarakat.

\section{PENUTUP}

\section{Kesimpulan}

1. Tindak Pidana Korupsi pada umumnya memuat efektivitas yang merupakan manifestasi dari perbuatan korupsi dalam arti luas mempergunakan kekuasaan atau pengaruh yang melekat pada seseorang pegawai negeri atau 
istimewa yang dipunyai seseorang didalam jabatan umum yang patut atau menguntungkan diri sendiri maupun orang yang menyuap sehingga dikualifikasikan sebagai tindak pidana korupsi dengan segala akibat hukumnya yang berhubungan dengan hukum pidana. Segala kejahatan sebagaimana dirumuskan dalam Pasal 46, Pasal 47, Pasal 47 a, Pasal $48 \quad$ Undang-Undang No. 10. Tahun 1998 yang dilakukan untuk memperkaya diri sendiri, orang lain atau korporasi sehingga menimbulkan kerugian negara merupakan bentuk korupsi di bidang perbankan.

2. Penyebab terjadinya korupsi di bidang perbankan dapat dilihat dari berbagai aspek, yaitu dari aspek pelakunya, aspek lingkungan/masyarakat dan aspek perundang-undangan. Penegakan hukum dalam hal pencegahan dan pemberantasan (upaya penanggulangan) korupsi di bidang perbankan dapat dilakukan melalui sarana penal (penggunaan hukum pidana dan hukum administrasi pidana) dan sarana non penal (lebih kepada peningkatan sistem pengawasan, penerapan prinsip kehati-hatian, menetapkan jaring pengaman sektor keuangan (financial safety net), pemantapan sistem perbankan yang mengarahkan perbankan kepada praktik-praktik goodcorporate governance. serta sosialisasi terhadap masyarakat). Karena Korupsi merupakan perbuatan yang melawan hukum, maka perlu ditingkatkan profesionalisme aparat penegak hukum dalam pencegahan dan pemberantasan tindak pidana korupsi di bidang perbankan. Penerapan sanksi lebih berat lagi, perlakuan terhadap pelaku pun tidak boleh diskriminasi sehingga ada efek jerah bagi pelaku.

\section{Saran}

1. Dalam hal penegakan Hukum terhadap kasus tindak pidana korupsi diharapkan aparat penegak hukum baik jaksa, hakim dapat menggunakan UU Tipikor untuk menjerat kasus tindak pidana korupsi di bidang perbankan.

2. Perlu adanya upaya penanggulangan korupsi di bidang perbankan melalui sarana penal (penggunaan hukum pidana dan hukum administrasi pidana) dan sarana non penal (lebih kepada peningkatan sistem pengawasan).

\section{DAFTAR PUSTAKA}

\section{A. Buku}


Ahmad Fuad, Penegakan Hukum dan

UpayaPencegahanTerhadap

Kejahatan Perbankan, Makalah

disampaikan pada Seminar

Nasional Penegakan Hukum

dan Upaya Pencegahan

Terhadap Kejahatan

Perbankan, Sekolah Tinggi

Hukum Bandung (STHB), 16

Juni 2011.

Badan Pengawasan dan Pembangunan,

Strategi Pemberantasan

Korupsi Nasional, Edisi Maret, 1999.

Edi Setiadi dan Rena Yulia. Hukum Pidana Ekonomi, Graha Ilmu,Yogjakarta, 2010.

Edi Setiadi, Hukum Pidana Ekonomi, penerbit Fakultas Hukum Unisba, Bandung, 2004.

Hartanti, Evi. Tindak Pidana Korupsi,

Sinar Grafika, Jakarta, 2005.

Klitgaard, Robert.Penuntut

Pemberantasan Korupsi dalam Pemerintahan Daerah, Yayasan

Obor Indonesia, Jakarta, 2002.

Muh Arief Effendi,.The Power of Good Corporate Governance, Teori dan Implementasi, Edisi 2, Salemba Empat.

Mulyadi, Lilik. Tindak Pidana Korupsi di Indonesia Normatif, Teoritis, Praktik dan
Masalahnya, $\quad$ Alumni, Bandung, 2007.

Moch. Anwar, H. A. K. Tindak Pidana di Bidang Perbankan, Alumni, Bandung, 1986.

Sholehuddin, M. Tindak Pidana Perbankan, PT. Raja Grafindo Persada, Jakarta, 1997.

Sudarto. Hukum dan Hukum Pidana, Alumni, Bandung, 1986.

Yopi Gunawan dan Kristian. Tindak Pidana Perbankan, CV Nuansa Aulia Bandung, 2013.

Yopi Gunawan dan Kristian. Tindak Pidana Perbankan Dalam proses Peradilan Di Indonesia, Edisi Pertama, Prenadamedia Group, 2018. 